\title{
Changes of Chloroplast Ultrastructure and Plastid Nucleoids during Greening under Light in Etiolated Fig Leaves (Ficus carica)
}

\author{
Naosuke $\mathrm{N}_{\mathrm{II}}{ }^{1}$ and Tsuneyoshi KuroIwA ${ }^{2}$ \\ ${ }^{1}$ College of Agriculture, Meijo University, Tempaku, Nagoya 468 \\ ${ }^{2}$ Department of Biology, Faculty of Science, University of Tokyo, Hongo, Bunkyo, Tokyo 113
}

\begin{abstract}
Summary
The greening process in etiolated fig leaves (Ficus carica L.) upon illumination with respect to the change of chloroplast ultrastructure and plastid nucleoids (pt-nucleoids) was studied with optical and transmission electron microscopy. With enlarging leaf size on the different nodal positions under dark conditions there were typical changes in the mesophyll including plastid morphology and synthesis of the lamellar system. Much of the starch disappeared, while rapid membrane synthesis resulted in an extensive prolamellar body formed in the plastid in the dark. During greening in the light after being transferred from dark conditions, leaf area, palisade parenchyma cells and intercellular spaces developed rapidly. The prolamellar body disappeared immediately after illumination. Increased membrane appression in chloroplasts was indicative of illumination, although overlaps had already begun to form in the dark. Changes in pt-nucleoids in etiolated fig leaves or during greening were followed by fluorescence microscopy after staining with DAPI (4',6-diamidino-2-phenylindole). Relatively large pt-nucleoids were first located in the plastids in the etiolated younger leaf, then daughter pt-nucleoids divided off and separated from these larger pt-nucleoids with development of the plastid. Upon illumination, pt-nucleoids were more separated from each other and were distributed evenly in the chloroplast, suggesting a relationship between formation of the thylakoid system and the behavior of pt-nucleoids.
\end{abstract}

\section{Introduction}

The relationship between the development of various leaf components during ontogeny is integral to our understanding of leaf function. Anatomical features of the chloroplasts in mesophyll cells and the final numbers of chloroplasts per cell will be particularly important determinants of leaf function, viz. photosynthetic rate. In addition, an intimate relationship, for example binding, between photosynthetic thylakoid and chloroplast chromosome may occur during greening (5).

The presence of plastid nucleoids (pt-nucleoids) and their automous replication in plastids has been well-established $(5,9)$. The dynamic behavior of ptnucleoids has been partially characterized during the proplastid (leucoplast) development towards a chloroplast (6). In wheat, Miyamura et al. (6) tried to characterize changes of pt-nucleoids during leaf

Received for publication January 24, 1990. development up to the stage of greening in order to clarify the plasticity of the genetic material in plastids. In this field, there have been few reports concerning fruit trees.

In the present work, the number and distribution of nucleoids in plastids of fig leaves during the greening process from etiolated leaves have been investigated by fluorescence microscopy. Concurrently, the ultrastructural changes of chloroplasts were estimated by transmission electron microscopy. Moreover, leaf growth, plastid growth and replication, and chlorophyll synthesis were assessed.

As part of a comprehensive research program on leaf structure-function relationships, fig leaves were chosen for investigation largely because there are less chloroplasts per palisade cell than in other temperate fruit trees and the appearance of $\mathrm{pt}$ nucleoids is easy to detect by DAPI (4'6diamidino-2-phenylindole) staining. 


\section{Materials and Methods}

\section{Plant materials}

One-year-old plants of fig (Ficus carica L.) propagated by hardwood cutting were used for the experiment. The hardwood cuttings for this study were provided from field-grown trees of fig in winter and were kept at $4^{\circ} \mathrm{C}$ after pruning until propagated. All plants were grown in dark conditions and only watered on alternate days. When the current shoots attained an average of $20 \mathrm{~cm}$ in June, etiolated leaves were divided under weak light into four different stages of leaf age classified by the individual nodal positions from the base on the current shoot (Fig. 1).

For the observation of the greening process with intact plants, dark-grown plants from hardwood cuttings were placed in a growth chamber at $25^{\circ} \mathrm{C}$ and illuminated continuously by fluorescent light at $22 \mu \mathrm{E} / \mathrm{S} \cdot \mathrm{m}^{2}$ as measured at the height of the plant. The leaves at the secondary position from the base on the current shoots were sampled at fixed time intervals $(0,15,40,60,160 \mathrm{~h})$ after illumination. The plants grown in continuous darkness were considered to have an illumination period of $0 \mathrm{~h}$. The process of greening was classified by content of chlorophyll measured by ethanol extraction (18) and included leaf area considerations.

\section{Optical and electron microscopic observation}

Morphological and anatomical data of the leaves were determined for etiolated leaves and for green-

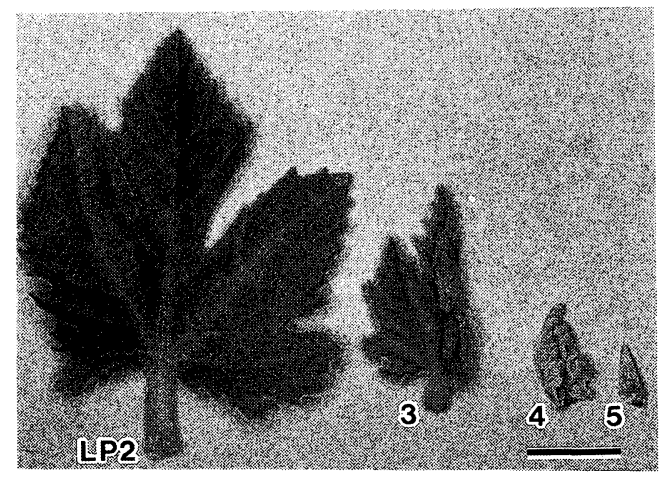

Fig. 1. The course of development of young fig leaves classified by the individual nodal positions from the base (LP2) to terminal (LP5) on the current shoot. $\mathrm{Bar}=1 \mathrm{~cm}$. ing leaves. The central area of the lamina was cut with a razor blade and was fixed in $2 \%$ glutaraldehyde for $2 \mathrm{~h}$ followed by $2 \% \mathrm{OsO}_{4}$ for $2 \mathrm{~h}$ at room temperature. All fixatives were prepared in $0.05 \mathrm{M}$ cacodylate buffer, $\mathrm{pH}$ 7.2. The fixed specimens were dehydrated through a graded ethanolacetone series and embedded in Spurr resin (14) and thin-sectioned $(2 \mu \mathrm{m})$ for light microscopy, after having been stained with methylene blue. For transmission electron microscopy, the ultra-thin sections were stained by the Reynolds Method (10). Comparisons of the appressed membrane in the thylakoid system at different stages of chloroplast development were based on observations from electron micrographs.

\section{Fluorescent microscopy}

The organization and arrangement of ptnucleoids in the plastids of etiolated leaves and in the chloroplasts during greening were studied with a light microscope using the fluorescent probe 4',6-diamidino-2-phenylindole (DAPI) which binds specifically to DNA (4). The number and size of chloroplasts in individual cells were also determined with a $100 \mathrm{X}$ phase contrast oil immersion lense on a Olympus photomicroscope.

\section{Results and Discussion}

Fig. 2 shows light micrographs of the etiolated leaves indicated by leaf position 2(LP2), 3(LP3), 4(LP4), and 5(LP5) from the base of the current shoot. Typically, leaf length and width increased with development from position 4 through 2 (Table 1). However, generally, palisade and spongy cells did not differentiate in the etiolated leaves at position 5 (terminal leaf, leaf length $6.8 \mathrm{~mm}$ ), 4 and 3. Etiolated leaves showed traces of chlorophyll even during darkness (Table 1); this level varied little with leaf age. Cell division in mid-lamina regions continued during the period of darkness (Fig. 2c). In addition, the marked decrease in size of cell nucleus appeared during cell division stage (LP3).

Electron micrographs illustrate the developmental sequence of dark-grown plastids found in each nodal position corresponding to leaf expansion from the terminal (leaf position 5) to leaf position 2 (Fig. 3). In dark-grown plants the plastids in leaf position 5 were longer and surrounded by a double outer membrane enclosing much starch in the 
form of one or more grains (Fig. 3a, 3b). No prolamellar bodies were observed at this stage. During morphological development of plastids with leaf expansion, highly differentiated plastids changed in both size and membrane synthesis (Fig. $3 \mathrm{c}, 3 \mathrm{~d}, 3 \mathrm{f})$. In many micrographs of leaf position 2 it was possible to select regions showing a transition of scattered thylakoids into a prolamellar body (Fig. 3e, 3f). There were one or two prolamellar bodies per chloroplast at leaf position 2 , where prolamellar bodies were found in about $50 \%$ of the plastids. When the prolamellar bodies

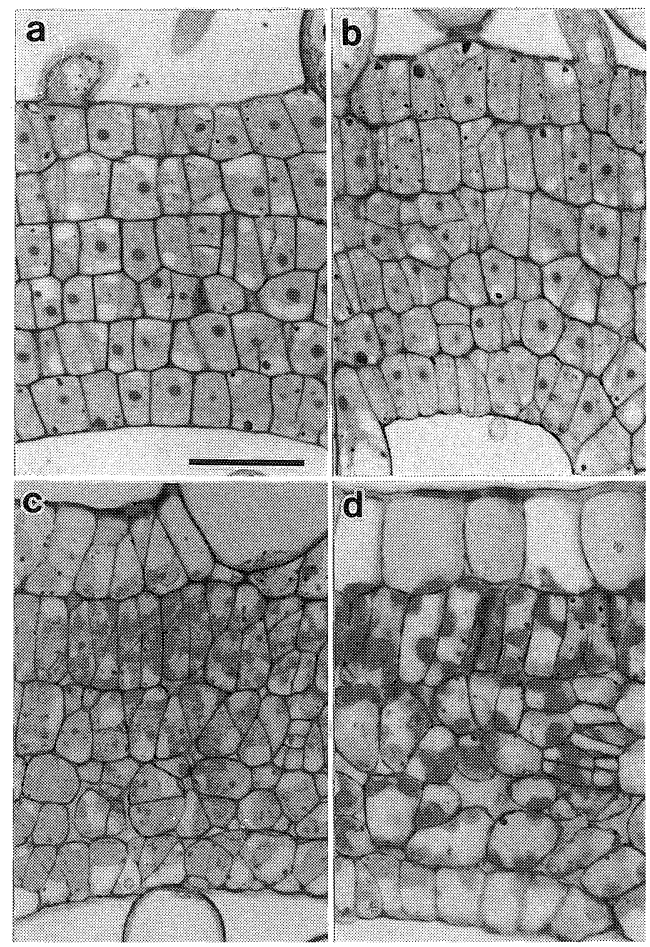

Fig. 2. Light microscope images of young fig leaves illustrating differences in mesophyll tissue grown under darkness.

a: leaf position (LP) 5 (terminal leaf), b: LP4, c: LP3, d: LP2. Bar $=20 \mu \mathrm{m}$. appeared in etiolated leaf plastids, there was less starch; there were invaginations of the inner membrane of the plastid envelope, as reported by other researchers $(15,17)$, and several vesicles in plastids, as described by Robertson and Laetsch (11). The structure of the prolamellar bodies was similar to that reported in leaf cells by other workers $(2,3,11,15,17)$. Plastids continued to develop in the absence of light with the expansion of leaf area and grana-like pairing occurred in dark-grown plastids, as observed by Robertson and Laetsch (11).

The effect of illumination on the leaves at leaf position 2 was followed throughout their development. The growth of the fig leaf had marked difference under light and dark conditions. During darkness the leaf did not reach a maximum size. Leaves expanded more rapidly after being transferred from dark conditions to illumination (Table 2 ). Thus, growth in each leaf, depending on the period under light, was mostly due to cell elongation of mesophyll and intercellular space development (Fig. 4). When the etiolated leaves were exposed to light, the prolamellar body rearranged rapidly into primary thylakoid layers (Fig. 5), and completely disappeared after $15 \mathrm{~h}$ of light. All leaves showed a significant change in plastid features under light (Fig. 5). There was also very rapid chlorophyll synthesis in light exposed leaves (Table 2).

In comparing developmental stages of each leaf during different periods of illumination, it appeared that morphological changes of plastids consist largely of increases in the amount of apparent thylakoids (Fig. 5). Grana developed rapidly when the etiolated leaves were exposed to light. These developmental changes were quantified by counting the number of layers of thylakoid membrane for each leaf and stage of development. After 15 $\mathrm{h}$ of light, there were usually one to three thylakoids extending into the stroma (Fig. 5a). After 40 or $60 \mathrm{~h}$ of light, more thylakoid layers appeared in

Table 1. Leaf area and chlorophyll content in fig leaves grown in the dark.

\begin{tabular}{ccrc}
\hline \hline $\begin{array}{c}\text { Leaf position } \\
\text { from the base }\end{array}$ & $\begin{array}{c}\text { Leaf length } \\
\times \text { width }(\mathrm{cm})\end{array}$ & $\begin{array}{c}\text { Leaf area } \\
\left(\mathrm{cm}^{2}\right)\end{array}$ & $\begin{array}{c}\text { Total chlorophyll } \\
\left(\mu \mathrm{g} / \mathrm{cm}^{2}\right)\end{array}$ \\
\hline 4 & $1.0 \pm 0.1 \times 0.6 \pm 0.1$ & $0.43 \pm 0.15$ & 0.88 \\
3 & $2.2 \pm 0.2 \times 1.7 \pm 0.3$ & $2.61 \pm 0.79$ & 0.71 \\
2 & $4.5 \pm 0.7 \times 4.0 \pm 0.6$ & $12.70 \pm 3.10$ & 0.91 \\
\hline
\end{tabular}



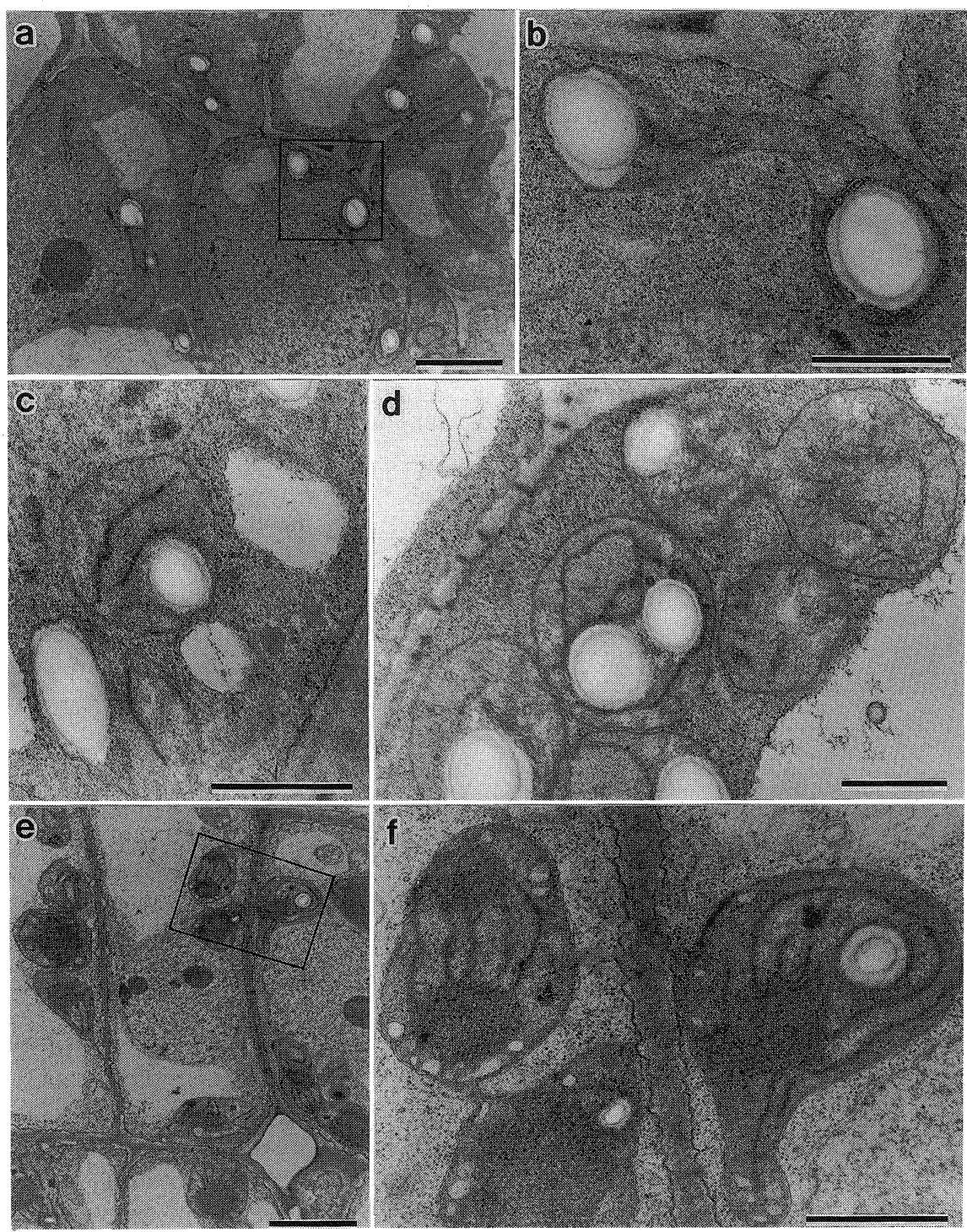

Fig. 3. Transmission electron micrographs of young fig leaves illustrating differences in plastid grown under darkness.

a: leaf position (LP) 5 (terminal leaf), b is detail from the boxed areas in a, c: LP4, d: LP3, e: LP2, f is detail from the boxed areas in e. Bar $=2 \mu \mathrm{m}(\mathrm{a}, \mathrm{e})$ and $1 \mu \mathrm{m}(\mathrm{b}, \mathrm{c}, \mathrm{d}, \mathrm{f})$.

Table 2. Leaf area, chlorophyll content, plastid and plastid-nucleoid frequencies in fig leaves after illumination.

\begin{tabular}{cccccc}
\hline $\begin{array}{c}\text { Illumination } \\
\text { period }(\mathrm{h})\end{array}$ & $\begin{array}{c}\text { Leaf length } \\
\times \text { width }(\mathrm{cm})\end{array}$ & $\begin{array}{c}\text { Leaf area } \\
\left(\mathrm{cm}^{2}\right)\end{array}$ & $\begin{array}{c}\text { Total } \\
\text { chlorophyll } \\
\left(\mu \mathrm{g} / \mathrm{cm}^{2}\right)\end{array}$ & $\begin{array}{c}\text { Chloroplast } \\
\text { per cell, range }\end{array}$ & $\begin{array}{c}\text { Plastid-nucleoids } \\
\text { per plastid }\end{array}$ \\
\hline 0 & $4.5 \pm 0.7 \times 4.0 \pm 0.6$ & $12.7 \pm 3.1$ & 0.91 & $8-12$ & $6.6 \pm 0.7$ \\
15 & $5.4 \pm 0.7 \times 4.8 \pm 0.5$ & $17.0 \pm 3.0$ & 1.89 & $8-13$ & $8.8 \pm 2.0$ \\
40 & $5.6 \pm 0.8 \times 5.3 \pm 0.7$ & $20.8 \pm 4.0$ & 9.73 & $9-14$ & $12.4 \pm 1.3$ \\
60 & $6.9 \pm 0.8 \times 6.3 \pm 0.7$ & $30.7 \pm 4.1$ & 16.84 & $9-12$ & $12.5 \pm 0.6$ \\
160 & $9.2 \pm 1.1 \times 9.7 \pm 1.3$ & $60.9 \pm 13.7$ & 36.02 & $9-12$ & $12.3 \pm 1.1$ \\
\hline
\end{tabular}



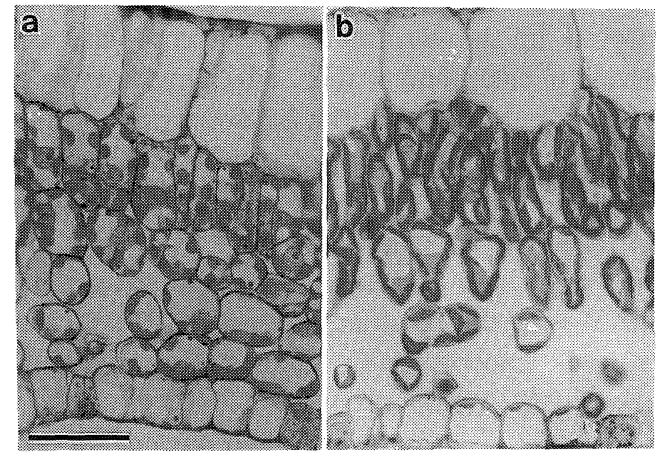

Fig. 4. Light microscope images of young fig leaves illustrating differences in mesophyll tissue after illumination.

a: illumination period (IP) $15 \mathrm{~h}$, b: IP $160 \mathrm{~h}$. Bar $=20 \mu \mathrm{m}$. the stroma (Fig. 5b, 5c), and after $60 \mathrm{~h}$ larger and more numerous grana were observed (Fig. 5 d): the fully differentiated chloroplast with large grana stacks. The development of plastids in light was marked by the association of thylakoid formation and chlorophyll synthesis.

The aim was to characterize plastid nucleoids during plastid development in leaves growing and aging in darkness (Fig. 6). However, it was not possible to count accurately nucleoids per plastid in younger and smaller leaves because the areas containing DNA were not as easy to resolve due to nucleoid aggregation in fig leaf plastids. Thereafter, in leaf position 4, the pt-nucleoids divided into approximately four pieces which became gradually spherical and located more or less in the peripheral region (Fig. 6c). At this stage starch
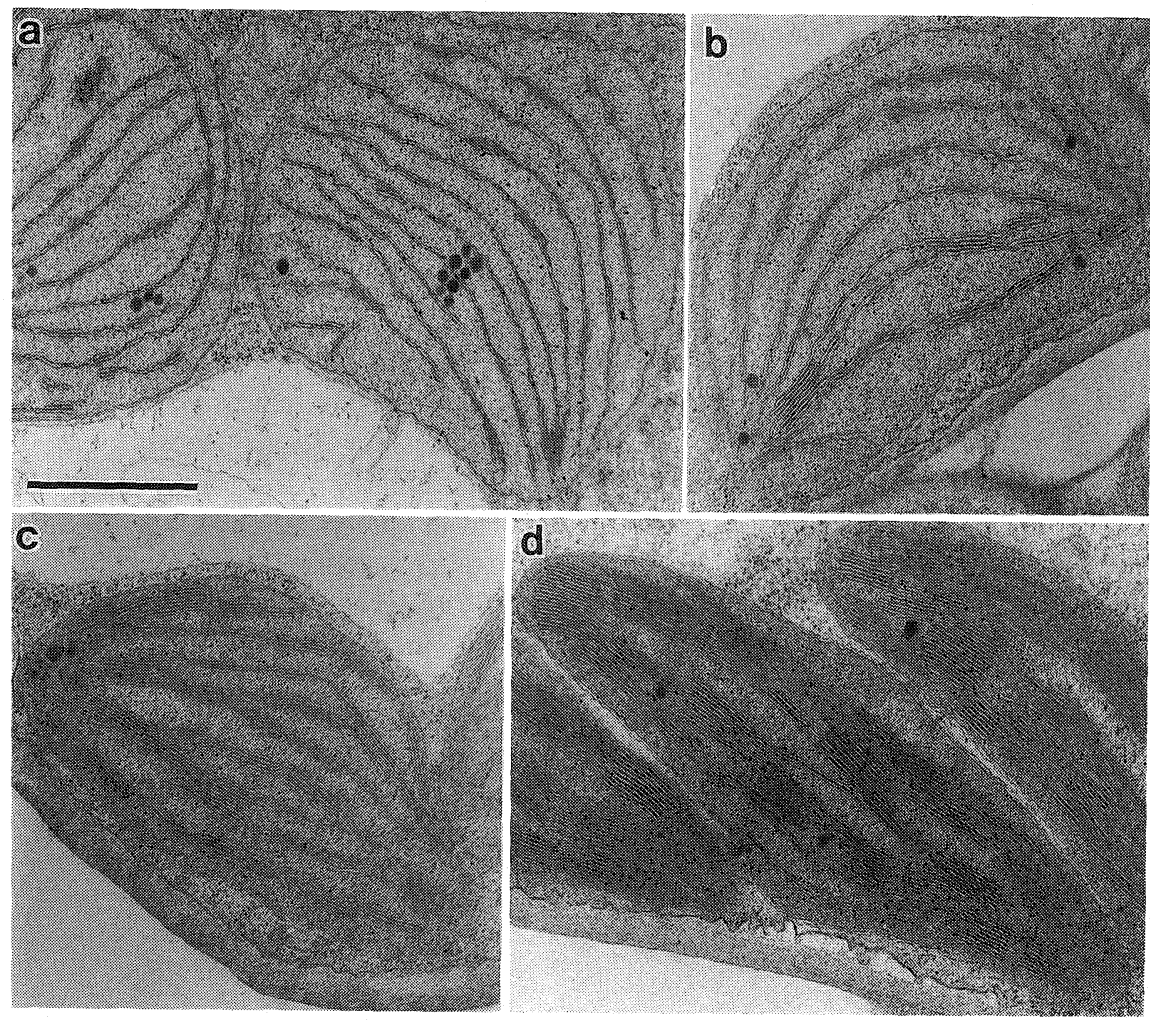

Fig. 5. Transmission electron micrographs of young leaves illustrating differences in plastid after illumination.

a: illumination period (IP) 15 h, b: IP $40 \mathrm{~h}$, c: IP 60 h, d: IP $160 \mathrm{~h}$. Bar $=1 \mu \mathrm{m}$. 
was still observed in the center of plastids and the formation of prolamellar bodies was not appeared (Fig. 3c).

When the prolamellar body became apparently in the plastids at leaf position 2 (Fig. 3f), pt-nucleoids were more divided and started to migrate in the plastids (Fig. 6e). At this stage the size of the fluorescent spots still varied considerably. Before light illumination and during leaf growth, daughter pt-nucleoids divided off from the central ptnucleoids. However, there was no clear arrangement of pt-nucleoids common for all chloroplasts, because plastid changes were not always synchronized in the dark. The spot size of pt-nucleoids was not uniform throughout leaf expansion in the dark nor after initial illumination.

From visual observations, nucleus size in the cell of enlarging leaves (LP3) was much smaller than those of younger leaves (LP4 and 5) (Fig. 2), and the plastid gradually became spherical with the appearance of membrane (Fig. 3). Changes of the number, size and distribution of pt-nucleoids appeared to be concomitant and correlation with such changes.

Upon longer illumination, smaller divided ptnucleoids migrated to the center of plastids (Fig. 7) and could be found between grana structures. Chloroplasts contained an average of 12 nucleoids (Table 2), which were more evenly distributed throughout whole plastids. This is, upon illumination, pt-nucleoids which had divided into ca. 6.6 pieces in the dark further sub-divided to give ca. 12 pieces which were then distributed in the central area of chloroplasts.

In the more developed chloroplast, by moving the focal plane through the plastids, it was evident that the discrete DNA region became randomly scattered in the stroma of the chloroplast with chloroplast enlargement (Fig. 7d). Thylakoid layers continued to increase in the light (Fig. $5 \mathrm{~d}$ ), with in general concomitant behavior of pt-nucleoids in the chloroplast. The even distribution of the nucleoids in fig chloroplasts of all light-grown plants is very district and differs markedly from the arrangement described for the plastids of wheat $(6,13)$. Our observations concord with chloroplasts of several species $(1,12,16)$.

Kuroiwa et al. (5) have classified nucleoids of mature plastids into five categories depending on their size, form, and distribution. According to this classification, chloroplast nucleoids in the mature fig leaves belong to the SN-type (even distribution of chloroplast DNA throughout the plastid). However, those at the early stage of plastids in dark-grown leaves were aggregated as one mass of DAPI staining material in the central region, as in young wheat chloroplast (6). At the next developmental stage, the type varied according to leaf age, semiperipheral location at the outer region of plastids and division of pt-nucleoids. In the more developed, particularly under illumination, discrete DNA masses were randomly scattered in the stroma of the chloroplast.

Miyamura et al. (6) reported on structural changes of pt-nucleoids during wheat development using fluorescence microscopy after staining with DAPI; observations were quantified by microfluorometry. In the present experiment neither the amount of DNA nor the number of ptnucleoids per chloroplast and cell was determined. We only observed the size and distribution of ptnucleoids in relation to leaf development. When
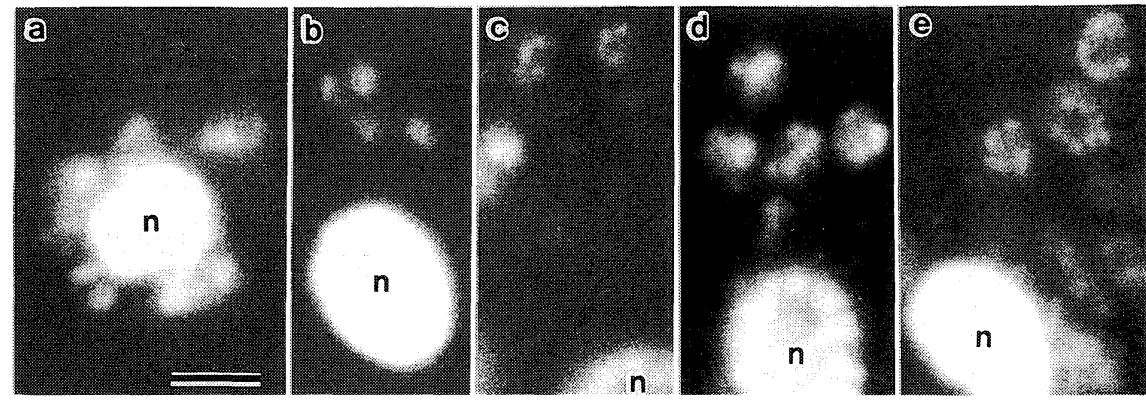

Fig. 6. Fluorescent micrographs reveal the central nucleus (n) and plastid nuclei after DAPI stain ing of young fig leaves grown under darkness. a: leaf position (LP) 6 (unopened leaf), b: LP5, c: LP4, d: LP3, c: LP2. Bar $=3 \mu \mathrm{m}$. 

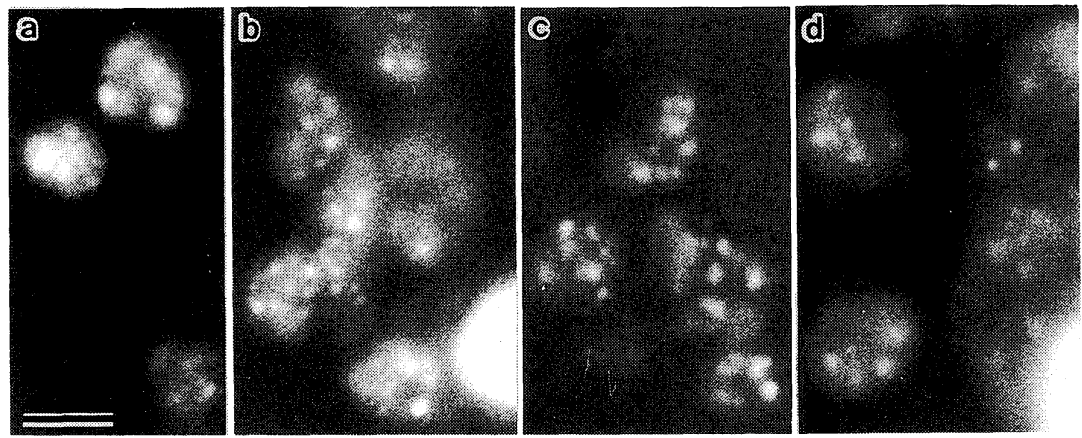

Fig. 7. Fluorescent micrographs reveal the chloroplast nuclei after DAPI staining of young fig leaves after illumination.

a: illumination period (IP) $15 \mathrm{~h}$, b: IP $40 \mathrm{~h}, \mathrm{c}$ : IP $60 \mathrm{~h}$, d: IP $160 \mathrm{~h}$. Bar $=3 \mu \mathrm{m}$.

the photosynthetic thylakoids in the chloroplasts of fig plants developed, pt-nucleoids divided into small pt-nuclei which were dispersed randomly throughout the chloroplast. As suggested by Miyamura et al. (6) binding may occur between photosynthetic thylakoids and chloroplast chromosomes in the greening stage of etiolated fig leaves. The present results are the first information of chloroplast untrastructural changes including arrangement of pt-nucleoids during greening in fruit trees, although such observations in peach leaves under different light conditions and during senescence have been studied $(7,8)$.

\section{Acknowledgement}

We thank Dr. S. Brown of the Service de Cytométrie, CNRS, Gif Sur Yvette, for his valuable advise and encouragement. This work was partly supported by Grants 86-133 from the National Institute for Basic Biology.

\section{Literature Cited}

1. Hansmann, P., H. Falk, K. Ronai and P. Sitte. 1985. Structure, composition, and distribution of plastid nucleoids in Narcissus pseudonarcissus. Planta $164: 459-472$.

2. IKEDA, T. 1970. Changes in fine structure of prolamellar body in relation to the formation of the chloroplast. Bot. Mag. Tokyo. 83 : 1-9.

3. Klein, S. and J. A. Schiff. 1972. The correlated appearance of prolamellar bodies, protochlorophyll(ide) species, and the Shibata shift during development of bean etioplasts in the dark. Plant Physiol. 49 : 619-626.

4. Kuroiwa, T. and T. Suzuki. 1980. An improved method for the demonstration of the in situ chloroplast nuclei in higher plants. Cell Struct. Func. $5: 195-197$.

5. Kuroiwa, T., T. Suzuki, K. Ogawa and S. KAWANO. 1981. The chloroplast nucleus: distribution, number, size, and shape, and a model for the multiplication of the chloroplast genome during chloroplast development. Plant Cell Physiol. 22 : 381-396.

6. Miyamura, S., T. Nagata and T. Kuroiwa. 1986. Quantitative fluorescence microscopy on dynamic changes of plastid nucleoids during wheat development. Protoplasma 133: 66-72.

7. NII, N. and T. KuroIwA. 1988. Anatomical changes including chloroplast structure in peach leaves under different light conditions. J. Hort. Sci. $63: 37-45$.

8. NiI, N., S. Kawano, S. Nakamura and T. KuroIWA. 1988. Changes in the fine structure of chloroplast and chloroplast DNA of peach leaves during senescence. J. Japan. Soc. Hort. Sci. 57 : 390-398.

9. Nishibayashi, S. and T. Kuroiwa. 1982. Behavior of leucoplast nucleoids in the epidermal cell of onion (Allium cepa) bulb. Protoplasma 110: 177-184.

10. Reynolds, E. S. 1963. The use of lead citrate at high $\mathrm{pH}$ as an electron opaque stain in electron microscopy. J. Cell Biol. 17 : 206-212.

11. Robertson, D. and W. M. Laetsch. 1974. Structure and function of developing barley plastids. Plant Physiol. 54 : 148-159.

12. Scott, N. S. and J. V. Possingham. 1980. Chloroplast DNA in expanding spinach leaves. J. Exp. Bot. 31 : 1081-1092.

13. Sellden, G. and R. M. LeECH. 1981. Localization of DNA in mature and young wheat chloroplasts using the fluorescent probe 4',6-diamidino- 
2-phenylindole. Plant Physiol. 68 : 731-734.

14. SPURR, A. R. 1969. A low viscosity epoxy resin embedding medium for electron microscopy. J. Ultrastructural Res. 26 : 31-43.

15. TOYAMA, S. 1972. Electron microscope studies on the morphogenesis of plastids VII. Effects of streptomycin on the development of plastids in tomato cotyledon. Bot. Mag. Tokyo. 85 : 89-103.

16. Tymms, M. J., N. S. ScotT and J. V. Possingham. 1983. DNA content of Beta vulgaris chloroplasts during leaf cell expansion. Plant Physiol. 71 : 785-788.

17. WEIER, T. E. and D. L. BRown. 1970. Formation of the prolamellar body in 8-day, dark-grown seedlings. Amer. J. Bot. 57 : 267-275.

18. Wintermans, J. F. G. M. and D. A. Mots. 1965. Spectrophotometric characteristics of chlorophylls and their pheophytins in ethanol. Biochim. Biophys. Acta. 190 : 448-453.

\title{
イチジクの黄化葉の緑化過程における葉緑体の微細構造と核様体の変化
}

\author{
新居直祐 ${ }^{1} \cdot$ 黑岩常祥 ${ }^{2}$ \\ 1名城大学農学部 468 名古屋市天白区 \\ ${ }^{2}$ 東京大学理学部 113 東京都文京区
}

\begin{abstract}
摘 要
暗条件下で育成したイチジクを明条件下に移し，黄 化葉の緑化過程における葉緑体の微細構造と核梯体の 変化を光学顕微鏡並びに透過型電子顕微鏡を用いて調 べた，暗条件下の個体について，葉の生長程度を葉位 別に比較したところ, 基部側の大きい葉ほど色素体の 発達やその膜構造の増加がみられるとともに, 葉肉組 織にも顕著な変化が観察された。暗条件下において, 色素体が発達するにつれてデンプン粒の大部分は消失 したが，色素体に現われたラメラ形成体に急速な膜生 成がみられた。暗条件下から明条件下に移すと, 緑化 とともに葉面積の拡大，栅状組織細胞や細胞間隙の発 達がみられた，光照射後，ただちにラメラ形成体は消

失した，色素体には暗条件下でもチラコイドの層状構 造がみられたが，明条件下に移すとこれがいっそう増 加し, 光照射時間と膜の層状構造の発達とはよく対応 していた. 黄化葉あるいは緑化過程にある葉の葉緑体 の核様体の変化を蛍光顕微鏡を用いた DAPI (4', 6-diamidino-2-phenylindole) 染色法によって観察し た. 若い黄化葉の色素体には比較的大きな核様体がみ られ，その後色素体の生長とともに核分裂し，互に分 離していった. 光照射によって, 核様体はさらに分離 し，葉緑体中に均一に分布するようになった。このこ とからチラコイド形成と核㥞体の挙動との間に関連が あるものと考えられる。
\end{abstract}

